\title{
A pioneer usage of nanogold sandwich ELISA in the detection of hydatid antigen in humans as a tool for improvement of serodiagnostic testing.
}

Waleed E Elawamy ( $\nabla$ waleedelawamy2015@yahoo.com )

Al-Jouf University https://orcid.org/0000-0002-5838-0494

\section{Samia M Rashed}

Benha University

Mona E Nassr

Benha University

Ibrahim R A Shalash

Theodor Bilharz Research Institute

Nagwa S Ali

Benha University

Amera S Elghanam

Benha University

Marwa M Nageeb

Benha University

Research article

Keywords: Hydatidosis, Protoscolices antigen, polyclonal IgG antibodies, Gold nanoparticles, Sandwich ELISA

Posted Date: February 6th, 2020

DOI: https://doi.org/10.21203/rs.2.21283/v2

License: (a) (1) This work is licensed under a Creative Commons Attribution 4.0 International License. Read Full License 
The authors have withdrawn this preprint from Research Square 